\title{
PCN site myiasis: a rarity
}

\author{
Saqib Mehdi, Satyanarayan Sankhwar
}

Urology, King George's Medical University, Lucknow, Uttar Pradesh, India

\section{Correspondence to}

Dr Saqib Mehdi:

mehdisaqib79@gmail.com

Accepted 10 January 2020

\section{DESCRIPTION}

A 38-year-old woman was referred to us as a case of uterovaginal prolapse with bilateral obstructive uropathy. On local examination, she was found to have fullness and tenderness in her bilateral flanks. Her routine blood investigations showed leucocytosis and raised serum creatinine levels. Her ultrasonography showed bilateral moderate hydroureteronephrosis. We performed an ultrasound guided bilateral percutaneous nephrostomy in the patient. She was referred back to the department of gynaecology where she was discharged home 5 days after being operated. The patient was from a far flung area with very poor access to healthcare. Patient reported to us in the outpatients department 4 weeks after her discharge from the hospital. On examination patient had bilateral nephrostomy tubes in situ but the dressings of both the tubes were soaked in foul smelling discharge. On removal of nephrostomy tubes foul smelling discharge was noted via both nephrostomy sites while live maggots were seen discharging from her right nephrostomy site (figures 1 and 2). On taking a detailed history she narrated the ode of inaccessibility of healthcare and poor hygiene at her native place. Patient was managed with application of turpentine oil locally at wound site and mechanical removal of all visible

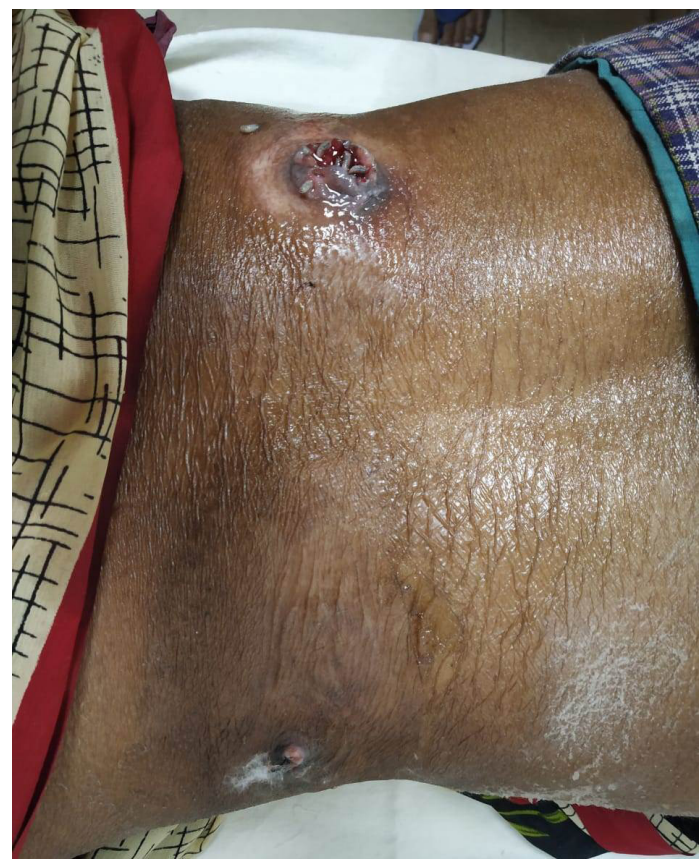

Figure 1 Clinical photograph of the patient showing both her nephrostomy sites exuding foul smelling discharge and live maggots discharging from the right nephrostomy site.

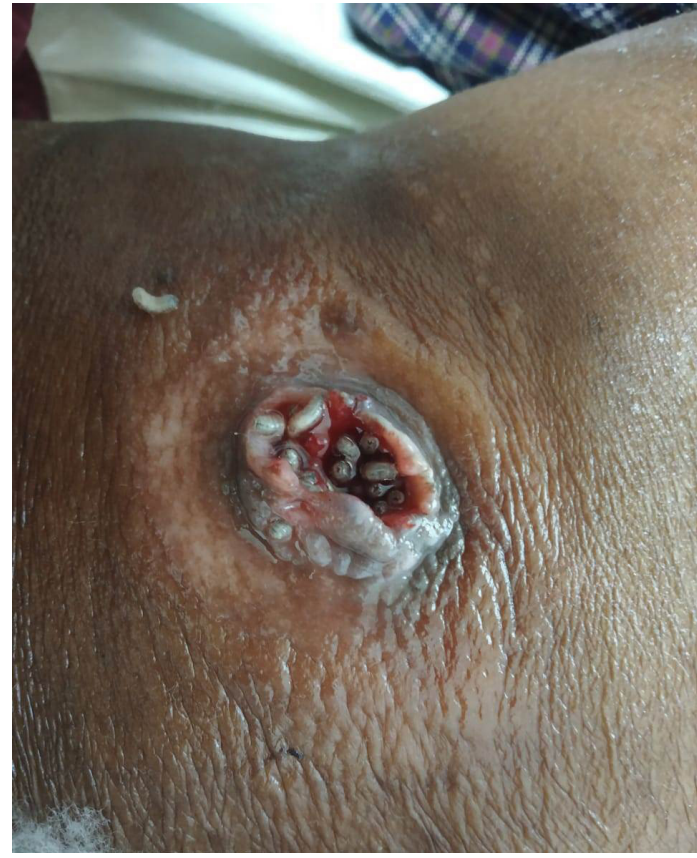

Figure 2 Clinical photograph with closer view of the patient showing live maggots discharging from right nephrostomy site.

maggots. She was followed with regular dressings and local wound care.

Myiasis are parasitic infestations of live human or vertebrate animal tissues or cavities. They are caused by dipterous larvae which feed on the host's dead or living tissue, liquid body substances or, if localised in the stomach, ingested food. ${ }^{1}$ Nephrostomy site infection is more common in tropical countries like India with poor socioeconomic status compounding the problem, as in our case the patient was unable to achieve proper wound care due to poor accessibility to a healthcare facility and poor hygienic conditions. Helpless or debilitated person, bleeding, decomposition, summer season and neglect in nursing care are the usual risk factors for infestation with myiasis. Treatment usually consists of mechanical removal of larvae. This may at times not be possible due to its tapered shape, many rows of spines and as the larvae may grip the tissue cavity by its hooks. Turpentine, mineral oil, ether, chloroform, ethyl chloride, mercuric chloride, creosote, saline, phenol, calomel, olive oil and iodoform can be used locally to ensure complete removal of all larvae, but in some cases wound debridement may be needed. Use of oral or topical ivermectin has also been described. A novel alternative method to these techniques has been mentioned that involves injection of lidocaine at the base of tissue cavity. The larvae inhabiting there are forced to the surface by 
local swelling where they are grasped and removed. ${ }^{23}$ Patients are advised regular dressings and maintenance of personal hygiene on follow-up.

\section{Learning points}

- Percutaneous nephrostomy being a common urological procedure, patients should be educated regarding the importance of regular dressings of the nephrostomy site.

- Maintenance of local hygiene and that of the surroundings cannot be overemphasised specially in less privileged sections of the society to ward off infestation of the wounds and other body sites with maggots.

- The treatment of myiasis may vary as per the affected site ranging from local elimination of the maggots mechanically/ chemically to the use of oral medication like ivermectin.
Contributors SM conceived the case report. SM and SS were major contributors towards writing the manuscript. SS and SM treated the patient, interpreted the patient data and were involved in the review. Both authors read and approved the final manuscript.

Funding The authors have not declared a specific grant for this research from any funding agency in the public, commercial or not-for-profit sectors.

Competing interests None declared.

Patient consent for publication Obtained.

Provenance and peer review Not commissioned; externally peer reviewed.

\section{REFERENCES}

1 Zumpt F. Myiasis in man and animals in the old world. London: Butterworth, 1965: 267.

2 Greenberg B. Two cases of human myiasis caused by Phaenicia sericata (Diptera: Calliphoridae) in Chicago area hospitals. J Med Entomol 1984;21:615.

3 Sunny B, Sulthana L, James A, et al. Maggot infestation: various treatment modalities. J Am Coll Clin Wound Spec 2016:8:51-3.

Copyright 2021 BMJ Publishing Group. All rights reserved. For permission to reuse any of this content visit

https://www.bmj.com/company/products-services/rights-and-licensing/permissions/

BMJ Case Report Fellows may re-use this article for personal use and teaching without any further permission.

Become a Fellow of BMJ Case Reports today and you can:

- Submit as many cases as you like

- Enjoy fast sympathetic peer review and rapid publication of accepted articles

Access all the published articles

Re-use any of the published material for personal use and teaching without further permission

Customer Service

If you have any further queries about your subscription, please contact our customer services team on +44 (0) 2071111105 or via email at support@bmj.com.

Visit casereports.bmj.com for more articles like this and to become a Fellow 